\title{
Assessment of the Link Between the Disseminations of Cash Crops and Water in Community Managed Small Scale Irrigation: Hare Small Scale Irrigation, Southern Ethiopia
}

\author{
Amsalu Kussia Chamaysha ${ }^{1}$, Abebe Temesgen Ayalew ${ }^{2, *}$ \\ ${ }^{1}$ Faculty of Water Resources and Irrigation Engineering, Arbaminch Water Technology Institute, Arbaminch, Ethiopia \\ ${ }^{2}$ Faculty of Hydraulic and Water Resources Engineering, Arbaminch Water Technology Institute, Arbaminch, Ethiopia
}

Email address:

teabeman@gmail.com(A. T. Ayalew)

*Corresponding author

\section{To cite this article:}

Amsalu Kussia Chamaysha, Abebe Temesgen Ayalew. Assessment of the Link Between the Disseminations of Cash Crops and Water in Community Managed Small Scale Irrigation: Hare Small Scale Irrigation, Southern Ethiopia. Journal of Water Resources and Ocean Science. Vol. 10, No. 2, 2021, pp. 16-25. doi: 10.11648/j.wros.20211002.11

Received: February 5, 2021; Accepted: March 24, 2021; Published: April 23, 2021

\begin{abstract}
In Ethiopia, the agricultural sector which is the vital sector in the economic development and poverty reduction. In this scheme, there are different groups of farmers who has been assumed to be the model and ordinary farmers by the current Ethiopian ruling party (FDRE). From this, the different farmers was selected from the model and ordinary farmers and grouped under the different investment models based on their crop choice. In the analysis, there are four elements of strategies through can get the water security. The location can influence the water access for the different water users. Based on this, the farmers located at the head-end while the farmers located at the tail-end of the scheme have the limited access for the water. Similarly, peoples can influence the water security through "know who". Based on this, the large plot holders and banana growers are concentrated at the head-end and middle of the scheme making the close contact with the water committees, they have the sufficient water access relatively compared with small plot holders and tail-enders. On the other hand, the farmers can get the water security from access to the technologies. From this regard, there is a recursive relationship between the distribution of water and the expansion of cash crops in the irrigation scheme. This recursive relationship is affected by the different strategies for securing access to water including the location of the plots, the "know-who", the creating of hydraulic property relations and the access to technology.
\end{abstract}

Keywords: Crop Choices, Investment Models, Hydraulic Property Relations, "know-who”, Hare Small Scale Irrigation

\section{Introduction}

Agriculture is the main economic activity in Ethiopia which is importantly the contributor for the country's gross domestic product (GDP). However, the recent studies shows that hence more than $80 \%$ of the society depends on the rain fed agriculture, the majority of the country's population is suffering from the lack of the food security due to the climatic variability $[3,20]$. The agricultural sector which is the important sector in the economic development and poverty reduction of the country performed strongly for the last decades to improve productivity and link it to the market. However, it remained dominated by the low input and output rain fed farming system leading to the insufficient household food security and high poverty levels $[2,1,12]$. In agricultural sector, Ethiopia has the strong set of policies and strategies to bring the country to the middle income countries. One of the basic pillar for the country's economic development is the agricultural development led industrialisation (ADLI) which had the completed plan for Accelerated and Sustained Development to End Poverty (PASDEP) and to launch Five Year Growth and Transformation Plan $[12,15,16]$. The main focus of Agricultural Development-led Industrialization (ADLI) strategy or guidelines is to bring the small-holder farmers to the efficient/proper utilization of modern agricultural technologies and increase the crop production of a lot of crops through expansion of small scale irrigation schemes in different areas under different geology, climate and topograpgic point of view $[13,11,9]$ 


\section{Materials and Methods}

\subsection{Description of Study Area}

Hare irrigation scheme is one of the small scale irrigation which is located in Abaya-Chamo sub basin, Gamo Gofa zone, rift valley Lake basin, Ethiopia. The water shed is situated between $6^{\circ} 03$ " and $6^{\circ} 18^{\prime \prime}$ North Latitude and $37^{\circ}$ $27^{\prime \prime}$ and $37^{\circ} 37^{\prime \prime}$ East Longitude with an area of $187 \mathrm{~km}^{2}$ as it is shown on Figure 1 below. The scheme is located at $495 \mathrm{~km}$ to the south of the capital city Addis Ababa. Its command area lies between $6^{\circ} 6^{\prime} 40^{\prime \prime}$ and $6^{\circ} 06^{\prime} 28^{\prime \prime}$ North latitude and $37^{\circ} 33^{\prime} 53^{\prime \prime}$ and $37^{\circ} 36^{\prime} 48^{\prime \prime}$ East Longitude with an area of 2224 ha. It is characterized by the semi-arid climate with an altitude of $1200 \mathrm{~m}$ m.s.l. its annual climate is rainy and dry seasons with the bimodal rainfall pattern having two rainy seasons per year, the minor rainy season from September up to November and the major rainy season from April up to June with the maximum rains between April and May. The scheme receives water from the Hare River which is one of the tributaries of Abaya- Chamo sub basin

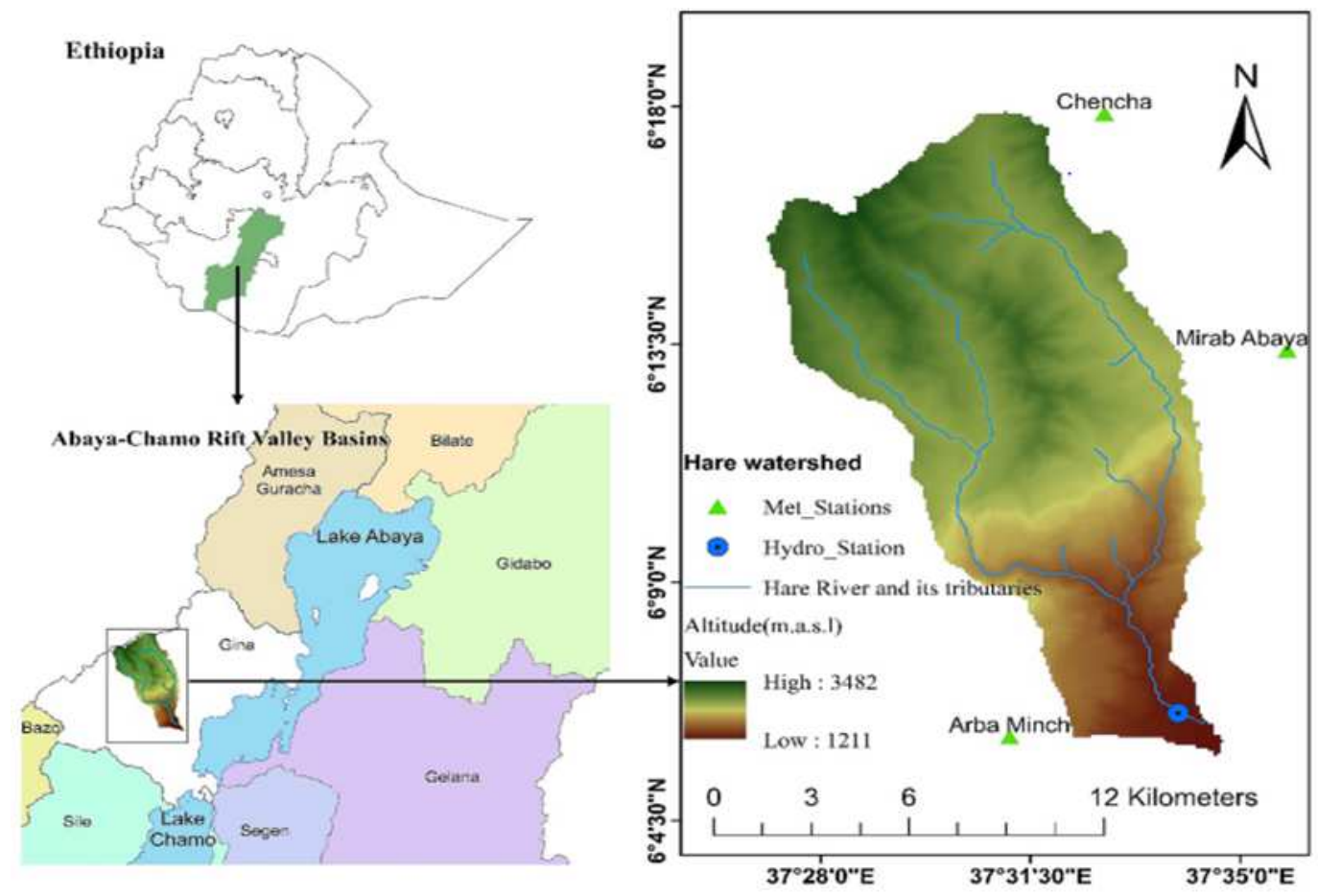

Figure 1. Location of Hare watershed.

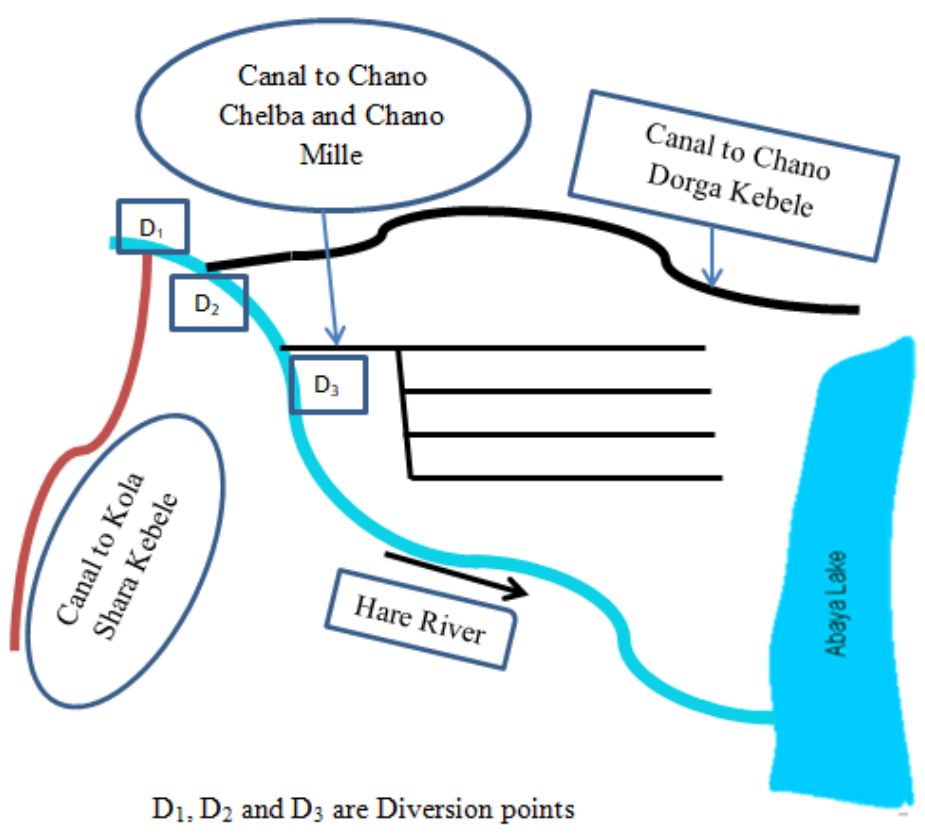

Figure 2. Hare irrigation scheme layout [4]. 


\subsection{Data Collection}

The relevant primary data was collected through the qualitative in-depth interview, group discussion, observation of the scheme, the important quantitative data including plot sizes and data on market prices for crops and measurements of water distribution using the floating methods. In Addition to this, the secondary data was obtained from different published and unpublished literatures such as books, peer reviewed journal articles, web pages and different reports regarding small scale irrigation in general and relation between the market value of the crops and water distribution in the small scale irrigations.

\subsection{Sample Selection for the Interview}

For our case study, we used the purposive sampling technique to select the different water users along the scheme to have a clear understanding about the study area. The total households under the Kolla shara irrigation scheme is approximately 500 families.

The interviewed households are selected based on the even distribution over the scheme from the head-end up to the tailend ( 5 households from the head-end, 5 households from the middle and 5 households from the tail-end of command area), their crop choices and life standards (wealth). The total of 62 households are interviewed from the farming and nonfarming families who are categorised under eight investment typologies as shown in Table 1. The farming families are composed of the original residents and the settlers from the other areas with different livelihoods (e.g. the rich farmers who are involving in the crop production and trading, the improved seed and fertilizers users and the low income families who have no access for the farm inputs) as their plots shown on figure 3. The other interviewed households are the water committees, the young families who did not make families with small plots, landless farmers who involves in the sharecropping, the members of the "kulaks 2" and female- headed households.

\subsection{Cash and Subsistence-Crop Farming}

Cash crop farming is growing the crops to be sold on the market to make the money. The cash- crops can be grains, fruits and vegetables. On the other hand, subsistence crop- farming is the practice of growing the crops for the in-house family consumption. Those farmers who are involving in the production of the subsistence crops to meet their own personal needs with little left for the markets are subsistence crop producers. In the subsistence farming, the farmers produce the crops based on the needs of the family while in cash-crop farming, farmers strategically produces crops to capitalize themselves by increasing the money. The farmers mostly grows the cash crops when they needs the capital to cover the costs of for instance fertilizer, land and farming equipment.

In the study area, small-holder farmers are dominantly involves in the production of banana which has high market value and mostly sold on the market. In addition, mango is produced as the market crops which are together with banana considered as the cash crops hence the farmers in the area produces this crops to be sold on the markets. On the other hand, maize and Teff are produced highly in the study area next to banana. The farmers involves in the production of maize and Teff for the family consumption. However, maize and Teff can be sold partly for the return of fertilizer debt and in need of the money for the family expenses. But, I identified banana as the cash crop and maize and Teff as subsistence crops.

\subsection{Distinction Between the Different Farming Households}

The households in the Kolla shara Kebele are composed of both farming and non-farming categorized in to six farming households and two non-farming households among eight household typologies to understand the level of their influence on the water distribution in the scheme. based on this, I identified the farming households and categorize as only cash crop producer (banana producers), cash crop producers and traders (families involving in the production of banana and trading of banana itself and mango), cash and subsistence crop producers (families involving in the production of banana, maize and Teff), cash and subsistence crop producers and traders (the families who are involving in the trading of banana and mango in addition to the production of banana, maize and Teff) and subsistence crop producers (the families who are involving only in the production of maize and Teff). Each household typologies are explained as follows;

Table 1. Table of the interviewed households.

\begin{tabular}{lll}
\hline S.No & Household groups & $\begin{array}{c}\text { Number of } \\
\text { interviews }\end{array}$ \\
\cline { 2 - 3 } & Farming households & 16 \\
\hline 1 & Cash crop producers & 2 \\
2 & Cash crop producers and traders & 28 \\
3 & Cash and subsistence crop producers & 1 \\
4 & Cash and subsistence crop producers and traders & 3 \\
5 & Subsistence crop producers & 3 \\
6 & Share cropping & \\
Other households & & 7 \\
1 & Daily wage laborers and landless households & 2 \\
2 & Traders of other goods rather than crops and other households & 62 \\
\hline
\end{tabular}




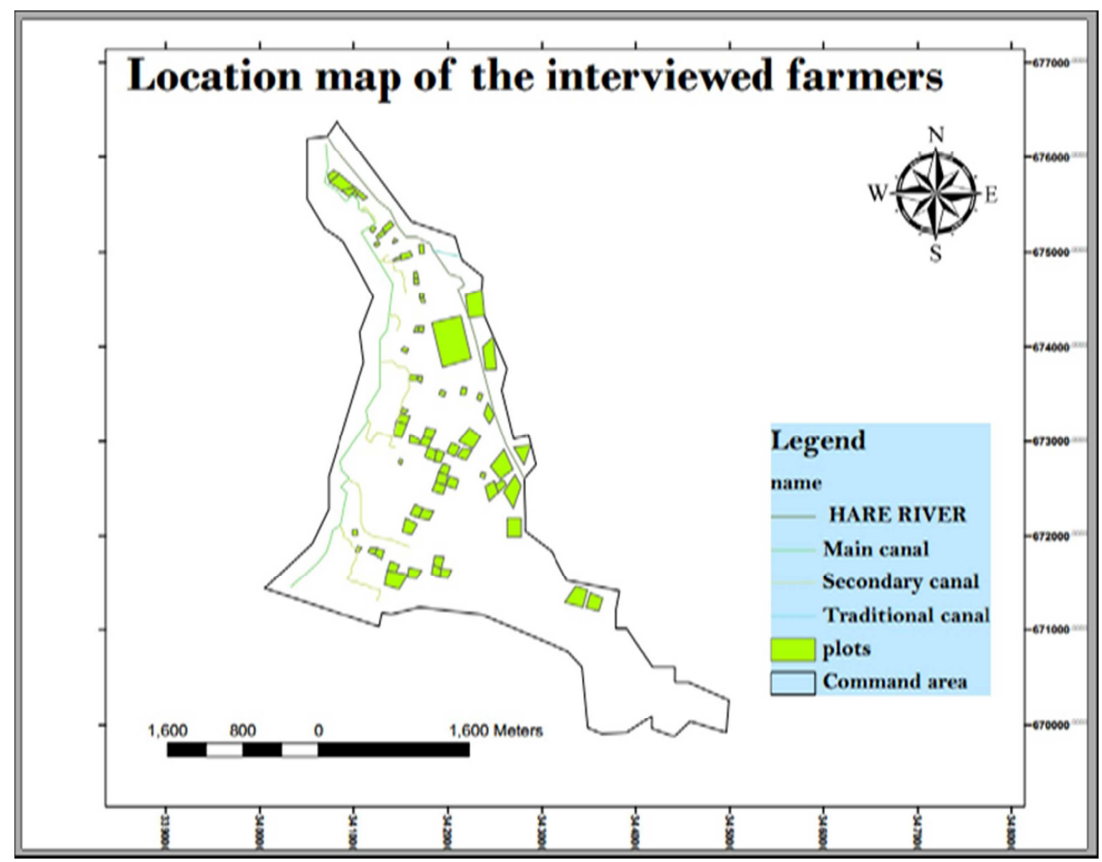

Figure 3. Location map of the interviewed farmers.

\section{Development of Kolla Shara Small Scale Irrigation}

\subsection{Planning and Design of the Scheme}

The three small scale irrigations making up the community managed Hare small scale irrigation are; the Kolla shara small scale irrigation with the modern diversion and traditional conveyance system, the Chano Dorga small scale irrigation with the traditional diversion and conveyance system and the Chano chalba and Chano mile small scale irrigation with the modern weir and the traditional conveyance system $[8,19]$. My study focuses on the Kolla shara small scale irrigation which is one of the three sub irrigation schemes of the Hare small scale irrigation scheme as it is shown on Figure 4. From the figure below, the map shows the total boundary of the Kolla shara Kebele administration. However, the part of the map bounded by the red (secondary canals) and blue lines (Hare River) is the command area of the Kolla shara irrigation scheme which is the hydraulic boundary even if some parts of the Kebele is found in the command area.

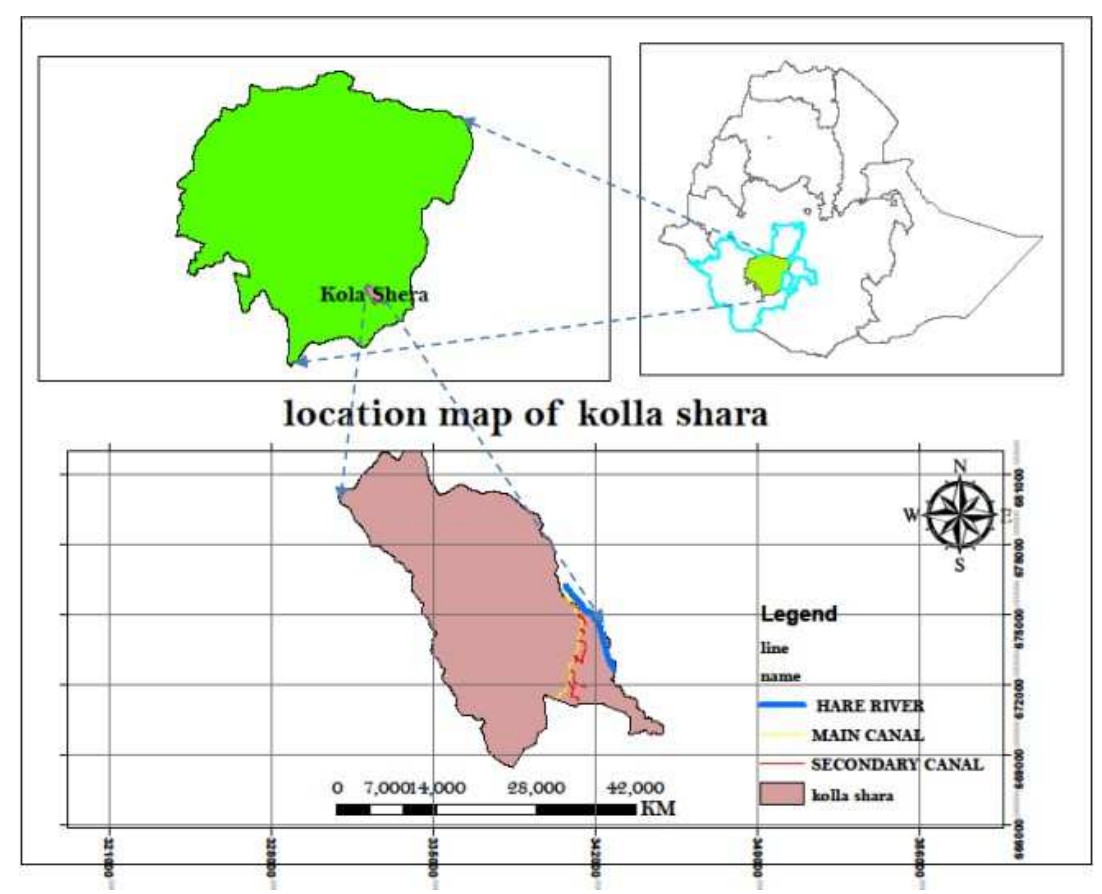

Figure 4. Location map for the Kolla shara irrigation scheme. 


\subsection{Traditional Planning and Design of the Scheme}

The irrigated agriculture was started in Ethiopia early 1960 's by the monarchical government to produce the industrial crops based on the development of the large scale irrigation. In the same way local farmers started to develop the traditional irrigations to divert the water from the river during the dry periods in order to produce the subsistence crops in the same year $[6,18]$.

As the local elders of the Kolla shara Kebele explained, during the monarchical regime starting from 1972, the people of the Kolla shara Kebele were reside along the banks of the Hare River. When the Derg regime was introduced, the plan of the Kolla shara Kebele was changed and people were relocated to about $2 \mathrm{~km}$ away from the river to safe the people from the flood damage of the Hare River. During the Derg regime in 1980 's, the elder people from the Kebele planned and opened the traditional canal from the Hare river to irrigate their garden fruits and vegetables and this canal was constructed by the group of people of the Kolla shara using the tree logs and the stones. Then the local people raised the question for the regional government to improve their canal into its appropriate alignment. Then the government make an agreement with the foreign nongovernmental organization (NGO), the Lutheran world federation (LWF) to construct the canal in to its appropriate alignment. Then the Lutherans changed the alignment of the canal and constructed the modern canal intake and unlined traditional canal with the length of $5.3 \mathrm{~km}$ in 1992 (interviews with F25 on Nov 27, 2015 and F32 on Dec 4, 2015).

\subsection{Modern Design of the Scheme}

The modern small scale irrigations were started in 1970's by the ministry of agriculture in order to resist the drought and starvation [6]. So the farmers in the Kolla shara Kebele have been developing the traditional irrigation for several years using the tree logs to divert the water from the river. However, after 1989, the Lutheran world federation (LWF) with the support of the community constructed the modern diversion and $5.3 \mathrm{~km}$ trapezoidal earthen canal for about 80,000ETB (see Figure 5). They support the community through providing the wheat aid and construction materials during the construction of the diversion intake with the height of $2.8 \mathrm{~m}$ and width of $1 \mathrm{~m}$ and irrigation water conveyance to irrigate the area of 617 ha $[8,17]$.

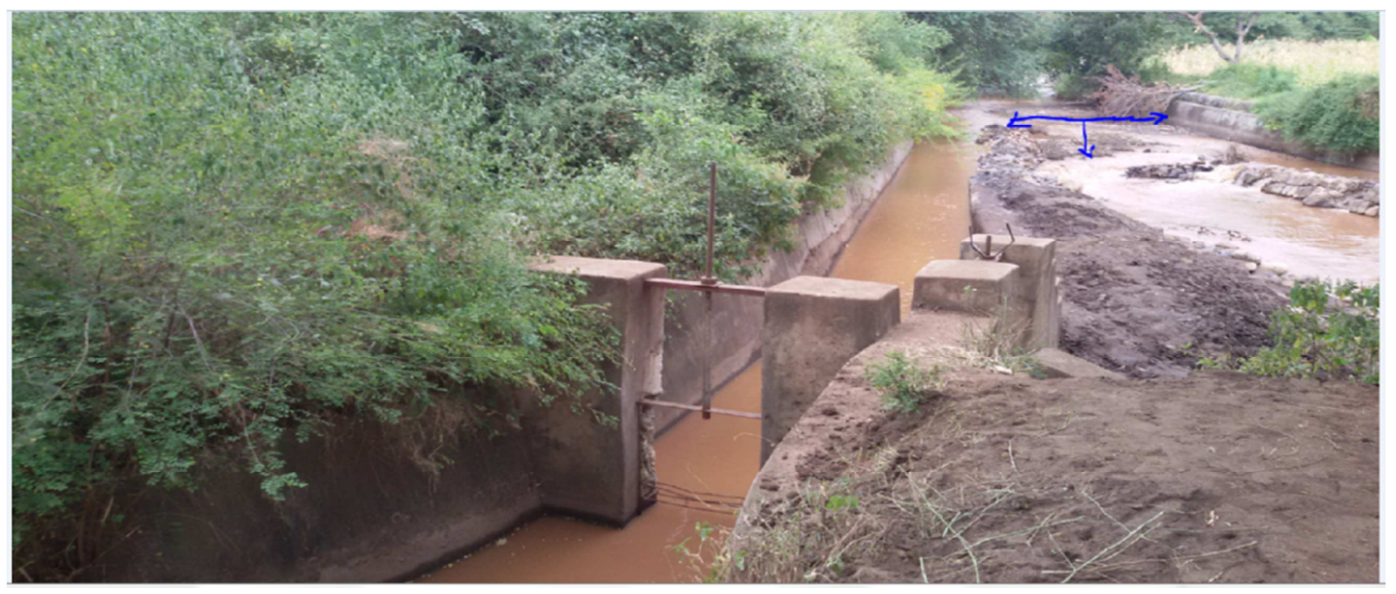

Figure 5. Location of diversion structure for the Kolla shara irrigation scheme.

Currently the Kolla shara small scale irrigation has seven secondary canals (SC) of which two of them have the division boxes which are constructed by the vita project in 1996 (see Figure 5). The rationale behind the construction of the division box on two secondary canals is hence there are high number of the water users under this secondary canals, the water is not distributed fairly for the water users under the main canal next to this secondary canals. This is difficult to manage and control the water and distribute it equally among the different water users. Considering this problems, the vita project which is nongovernmental organization constructed the gated division boxes on two secondary canals in order to control and release the water to the secondary canals and the main canal equally. The main canal is the contour canal that follows the same elevation points from its intake up the end with the length of $5.3 \mathrm{~km}$ and irrigating 617ha of command (interview with F24 on Nov 27, 2015).
The construction of the modern diversion structure and the extension of the main canal length increased the irrigable command area. The administrative boundary of the Kolla shara Kebele is not the same as the command area. However, the part of the command area located at the East of the Hare River (the plots and village of the "kulaks") as shown on Figure 6 was used to get water from the Kolla shara irrigation scheme after the downfall of the socialist Derg regime. However, due to the increase of water demand under the scheme, this area is not the part of the Kolla shara irrigation scheme. On the other hand, the area located at the most tailend of the scheme as shown in the figure below was the part of the Kolla shara command area. However, it is not receiving the water from the Kolla shara irrigation scheme. However, some of the farmers located on this area are constructed their own traditional canal to irrigate their plots alternatively. Some part of this area is the water logged (wet 
land) which is impossible for the crop production.

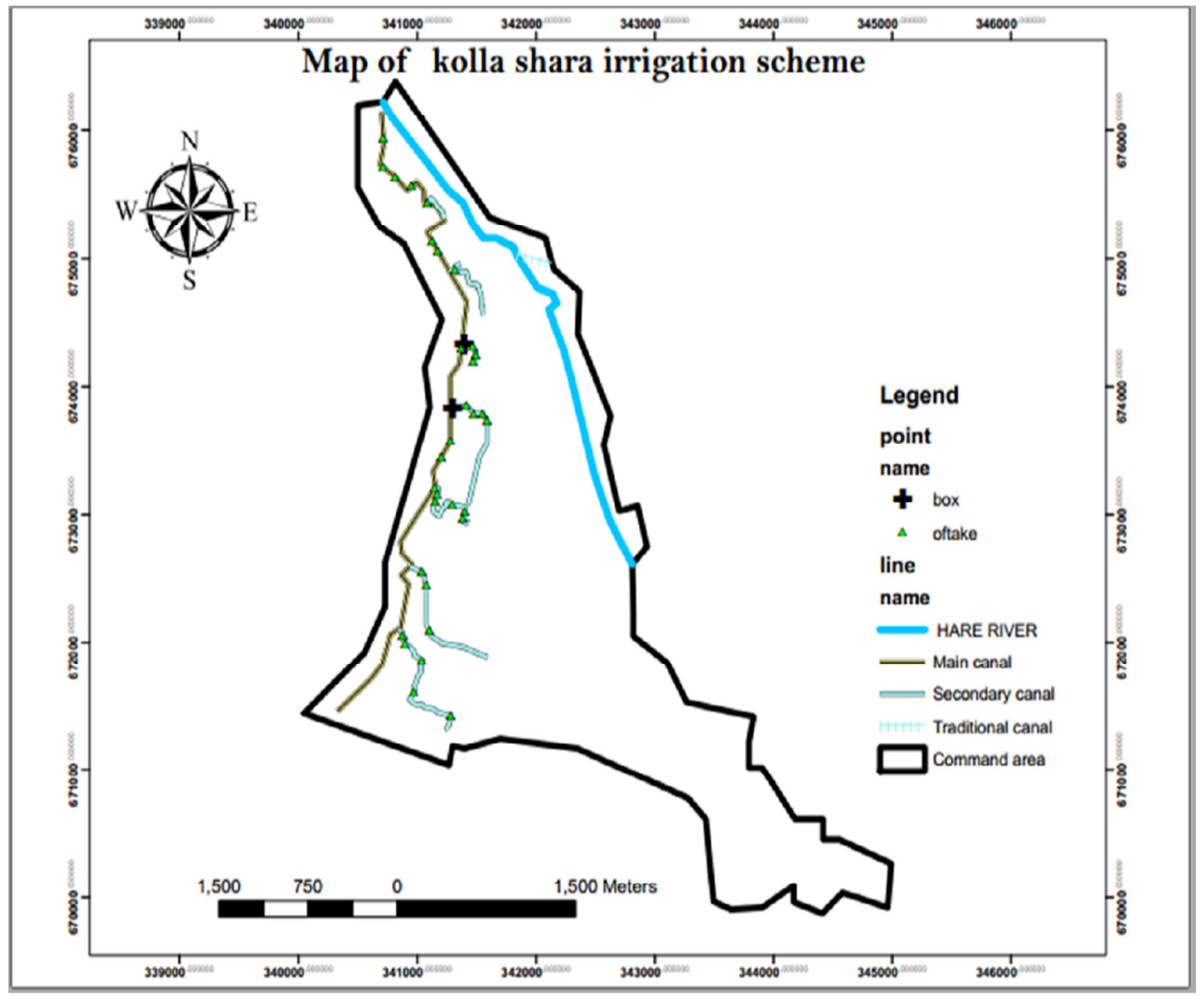

Figure 6. Layout of the Kolla shara main canal, secondary canals and field offtakes.

\subsection{Land Tenure and Marketing}

The current land holding in Ethiopia is based on the context of three different past systems; the feudal system (imperial regime) in which the land holding is based on the one's lineage (rist), the land allocation based on the orthodox church and the belongingness of the land to crown (Government). The other context is the Derg socialist government which assumed power by the military force in 1975 proclaimed to weaken the feudal land lords in which the university students protested the imperial regime with a slogan of "land to the tillers". In this regime, the land was allocated to the farmers with the right to use but without any transfer, sell, mortgage or lease. In the current 1995 Federal Democratic Republic of Ethiopian (FDRE) government context, the use but not transfer, sell and lease of the urban and rural land was given to the people hence the land is regarded as the common property of the "Nations, Nationalities and Peoples of Ethiopia" as vested in article 40 of the FDRE constitution [7, 5, 14].

\subsection{Land Marketing}

As it was recognized on article 40 of the FDRE constitution, the rural and urban land is regarded as the property of the nation and nationality of Ethiopia which cannot be sold, mortgaged or leased. However, farmers are exchange their land in the case of the monetary shortage traditionally. In the Kolla shara Kebele, those who hold the large lands after the downfall of the Derg socialist government sells the land for those who are the landless. In this Kebele, they have their own traditional rule of the land marketing which is based on the agreement of the land seller and buyer. If the land has perennial crops (e.g. mango and avocado), it cannot be sold permanently. If it does not have the tree crops, the seller can sell it permanently or temporarily as a contract for some years and get it back. The land selling for the contract is based up on the agreement between the seller and the land buyer (i, e if the land is for the contract, the seller and the buyer agree on the perennial crops on the plot if it is possible or not to possible to grow the perennial crops on the plots). When they agree to not grow the perennial crops (I, e banana, mango and avocado), the land buyer used the plot to grow only the seasonal crops until he return it for the land seller or if they agree to grow the perennial crops, the buyer grows the perennial crops and return it for the seller at the end of the contract (interview with F43 on Dec 26, 2015).

\subsection{Cropping Pattern in the Scheme}

\subsubsection{Major Seasons in the Study Area}

In Ethiopian, there are four different seasons throughout the year. Summer (Meher) is the season with the heavy rain 
fall within the months (May-August). This is considered as season 2 in which the seasonal crops such as maize, sorghum and Teff mostly gives the high yield due to the sufficient rainfall. Autumn (Belg) is the season which is mostly considered as the end of harvest for season 2 (Meher) crops and planting (sawing) of the "Belg" crops. The Belg is considered as season 1 hence it exists at the beginning of the Ethiopian New Year in September. The months (SeptemberJanuary) are the months in which the Belg crops are grown. The winter (Bega) are the dry seasons which are the harvest season for the Belg crops. The months (January and February) are the dry season. Springs (Tseday) is the season in which the Meher crops grown with the shower rainfall. The months (March and April) are the autumn season with occasional showers 4.

\subsubsection{Crop Distribution}

The major crops grown over the Kolla shara scheme in the seasons mentioned described above are banana, maize, Teff, sweet potato, tomato, mango, avocado, pepper, papaya, lemon and cassava. These crops are categorised as the perennial crops which can stay through the year and the seasonal crops which are grown only in the wet seasons.

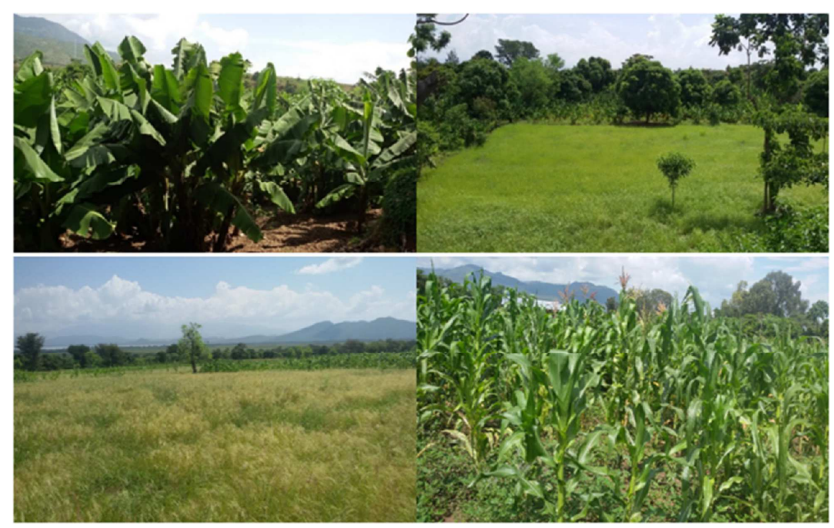

Figure 7. Major crops of the area.

Table 2. The command area covered by the different types of crops in the scheme in season 1 of 2015/16.

\begin{tabular}{lll}
\hline Crop type & Area covered (ha) & Remarks \\
\hline Banana & 174 & 143ha of the command area is occupied by the homes \\
Mixed crops & 193 & \\
Maize or Teff & 106 & \\
\hline
\end{tabular}

As water users explained during the interview, most of the farmers grow maize, sorghum and Teff at the tail-end of the command area in season 1 (Belg) and season 2 (Meher) when there is sufficient rainfall. Due to the high dependency of the seasonal crops on the water and its need for the in-house family food consumption, most of the farmers at the tail end prefers to grow

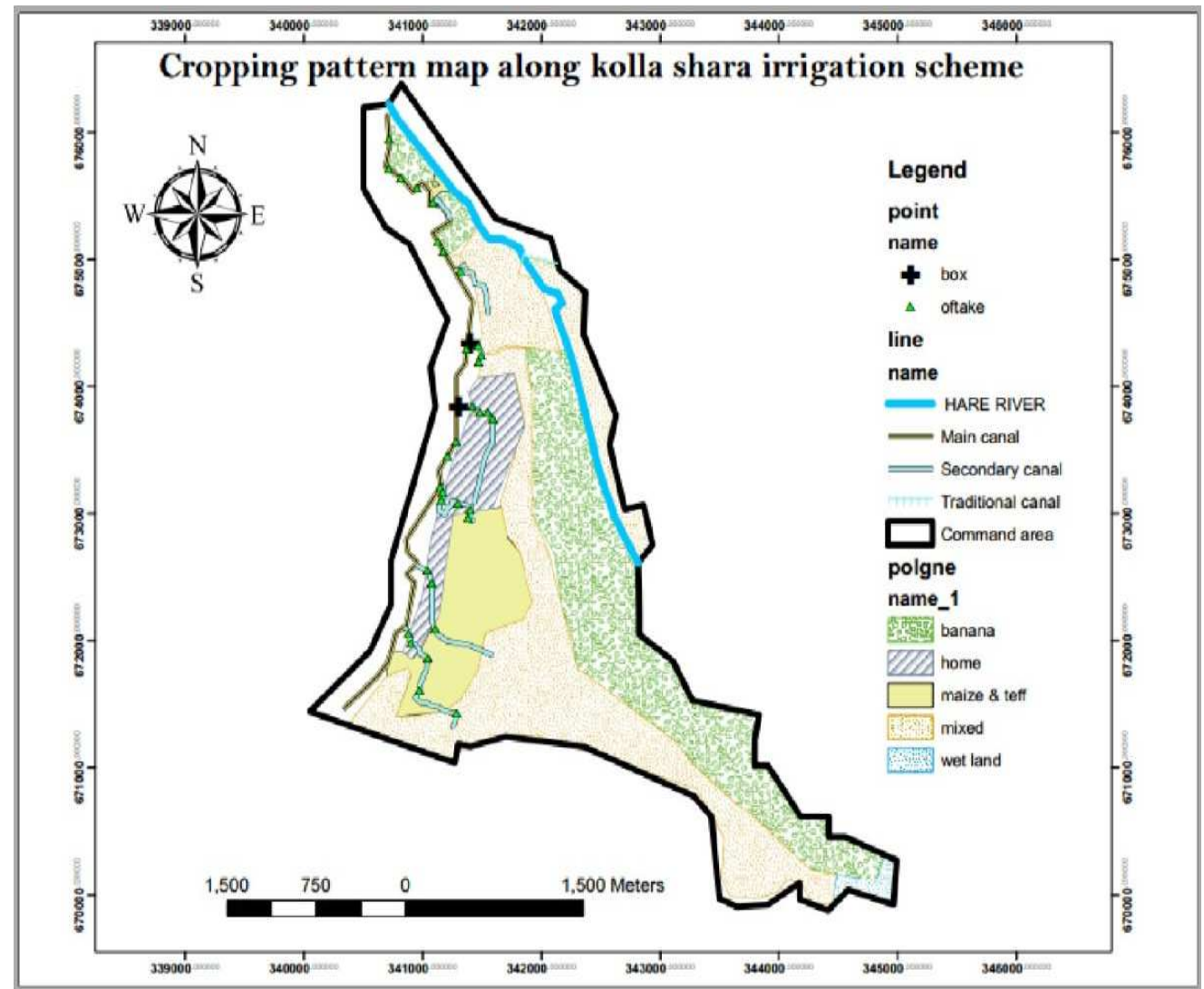

Figure 8. Map of the crop distribution over the Kolla shara command area. 


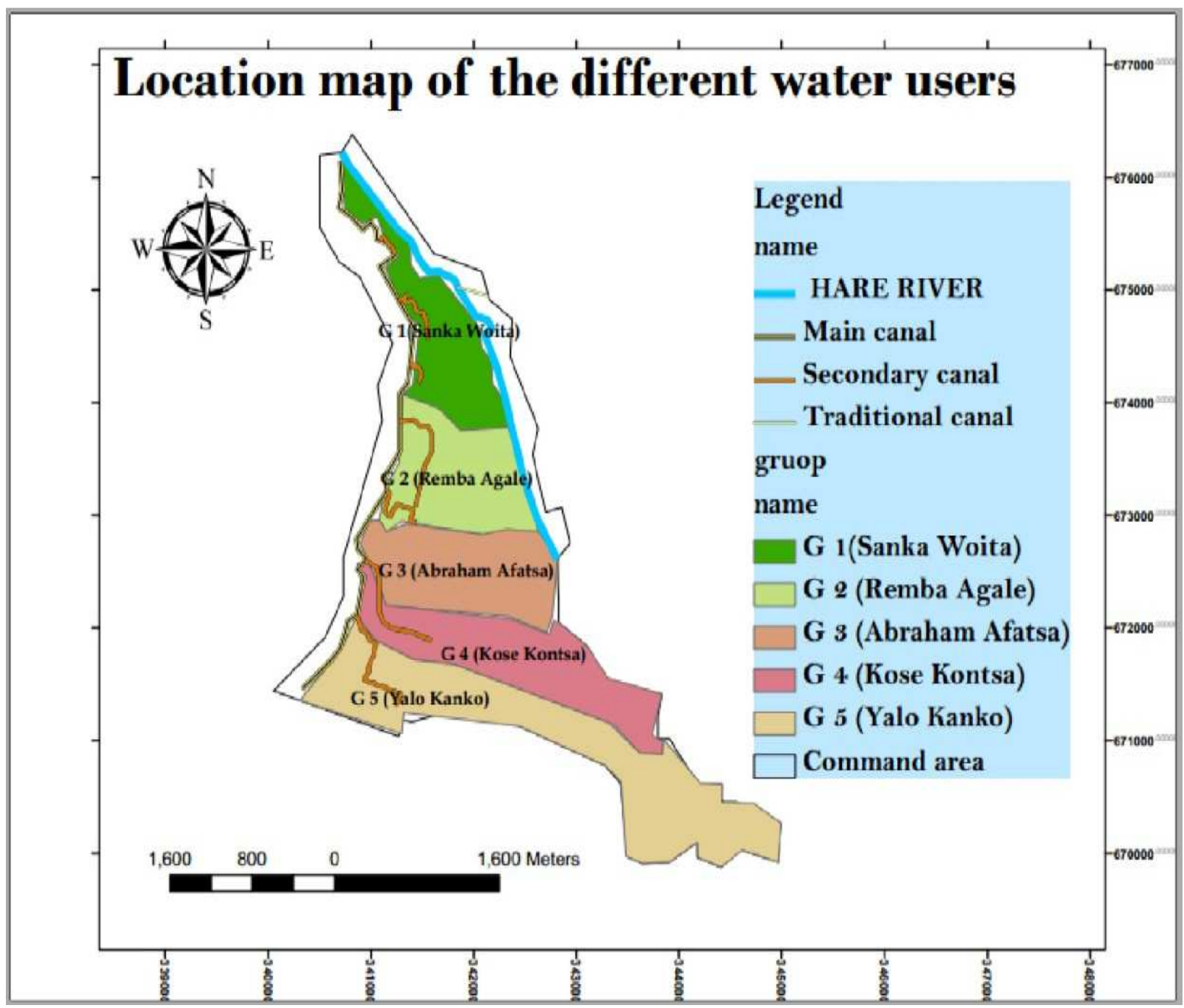

Figure 9. Map of different groups of the water users.

\subsubsection{Investment Models in Kolla Shara Scheme}

There are about eight diversified typologies of households distributed over the different investment models in the Kolla shara Kebele who are categorised as the model farmers, ordinary farmers and the other households (See Table 3). The most households who have high influence on the water distribution in the Kolla shara scheme are categorised under the model and ordinary farmers some of whom have the access for the farm inputs while the others do not have the access which leads them to have the different income and water access.

Table 3. The composition of the different household typologies in the Kolla shara Kebele.

\begin{tabular}{|c|c|c|c|c|}
\hline S.№ & Household typologies & Model Farmers & Ordinary farmers & Other households \\
\hline 1 & Only Commercial crop producers & $\sqrt{ }$ & $\sqrt{ }$ & \\
\hline 2 & Involved in Commercial crop production and trade but no subsistence crops & $\sqrt{ }$ & & \\
\hline 3 & Commercial and subsistence crop producers & $\sqrt{ }$ & $\sqrt{ }$ & \\
\hline 4 & Only subsistence crop producers & & $\sqrt{ }$ & \\
\hline 5 & commercial and subsistence crop producers and traders & $\sqrt{ }$ & $\sqrt{ }$ & \\
\hline 6 & Daily labourers & & & $\sqrt{ }$ \\
\hline 7 & Share cropping & & $\sqrt{ }$ & \\
\hline 8 & Traders of the other goods and families working in Government institutions & & & $\sqrt{ }$ \\
\hline
\end{tabular}

\subsubsection{The Investment for Various Household Typologies}

The terms "model" and "ordinary farmers" have been used after the election of 2005 of the current ruling party of Ethiopia (FDRE) to identify the economically advanced farmers 7 who are the party members and part of the rural elites in order to sustain the FDRE political domination [10]. The current ruling party identified these farmers who are more conscious politically and locally influential in their agricultural innovativeness (improving the agricultural yield 
using the new technologies).

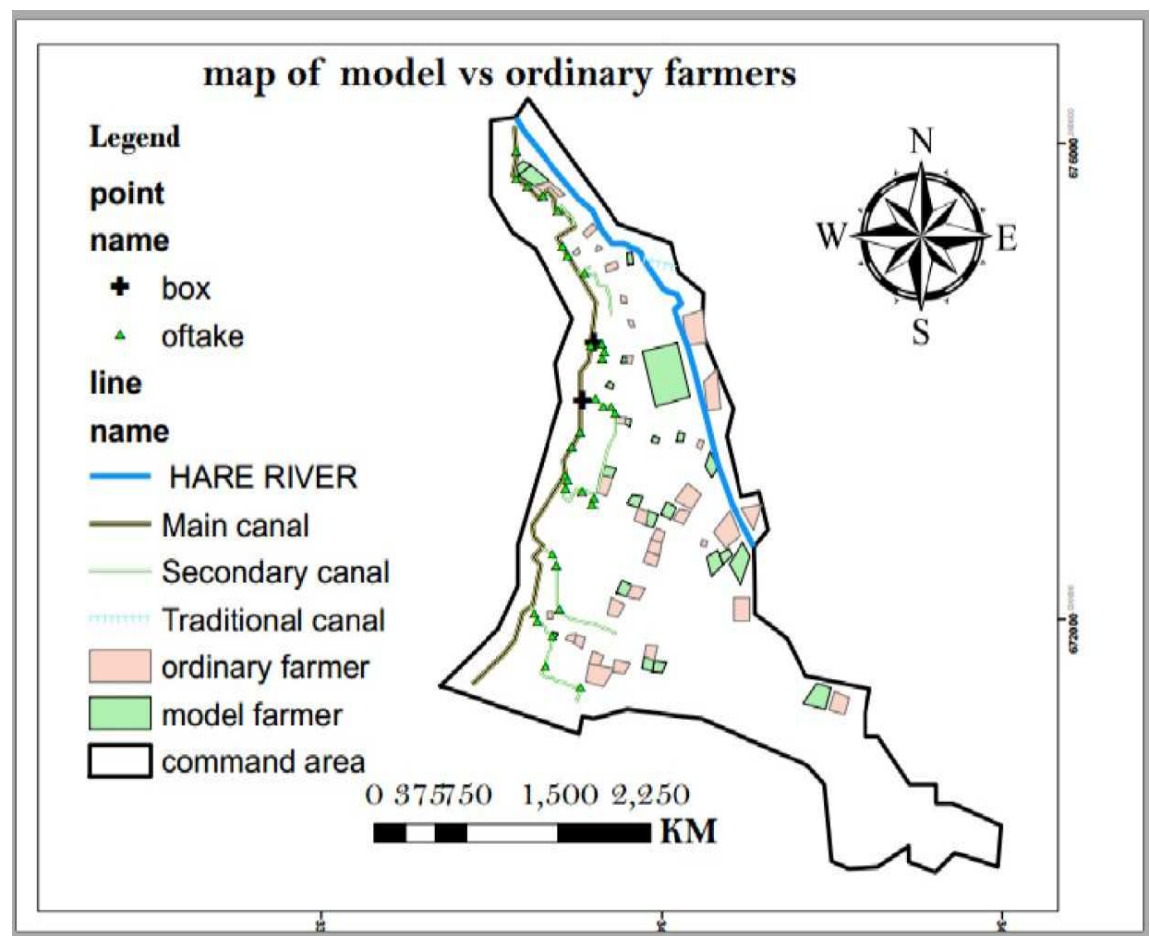

Figure 10. Map of the interviewed model and ordinary farmers.

From the data analysis this research shows that farmers who are producing the cash crops are more water secure while the farmers who are involved in the production of only subsistence crops have less control and access to water resources. The initial causal relationship between water distribution and cash crop expansion remains unknown. However, the field data shows a recursive relationship between water security and the location of the farm plots, "know-who", the hydraulic property relations and the access to technologies.

\section{Conclusions}

In general, also in this irrigations scheme, farmers located at the head-end have an advantaged position because they can (illegally) abstract water and in that way deny downstream water use. However, from the data it becomes clear that not all farmers located in the head-end can utilize this advantage as some of them still are water insecure and not involved in cash crop farming. Moreover, some farmers in the tail-end, even though they are located at a less advantaged location in the irrigation scheme, are water secure and involved in cash crop farming. This points to other aspects that also influence water security beside upstream-downstream asymmetries.

"Know-who" seems to play an important role in the irrigation scheme. First of all, "know-who" has played a role in allocating plots in the scheme (interview with F25 and F32 on Nov 27, 2015) and thus determines who is located at advantaged positions to secure access to water. Second, model farmers, who per definition are members of the ruling political party, are in general better off than ordinary farmers since none of the model farmers is only growing subsistence crops, even not those model farmers located at the water scarce tail-end. Third, farmers who are less water secure, even those located in the head-end of the irrigation scheme, are farmers who have less strong relationships with the water committees and other actors influential in the decision making processes in the irrigation scheme. Further, I analysed how "know how" is related to maintenance and access to technology.

On the other hand, also the actual creation of hydraulic property relations does play a role besides "know-who". The WUA of the Kolla shara scheme has the rule that the femaleheaded households whose children are less than 18 years and the old people have the right for the water access without participating in the canal cleaning and repair. However, one of the female- headed households in the scheme has limited water access and one of the elders was restricted from accessing the water for two successive seasons. This shows that they are denied from the access to water because they have not invested in the collective infrastructure and thus are excluded based on the absence of hydraulic property rights. Remarkably, farmers with small plots located at the most tailend of the scheme which currently not receiving water from the irrigation canals, are involved in the canal cleaning works. Potentially they do this to establish hydraulic property rights to secure the access to water for the alternative uses (for their cattle drinking from the canal, washing, house constructions etc.).

However, there are some farmers without advantaged plots, without hydraulic property rights on the scheme and 
without "know-who" but can still be water secure and involved in cash crop production because they have alternative ways of accessing water by digging a private canals (furrow), pumping water straight from the river or rely on the naturally available groundwater sources in some parts of the scheme. These farmers are located within the original command area of the irrigation scheme. However they are no longer part of the irrigation system.

Additionally, it is identified that the farmers who are involving in the trading of the cash crops have the advantages over the farmers who only involves in the subsistence crop production. This affects the farmers who involves only in the subsistence crop production during the high production when the price of the crops reduces and leads them to faces difficulties to pay back the debt of the fertilizers. In this case, the farmers who involves in the trading take their yields to the distant markets where the price is higher which indirectly sustain their water security hence they are continue to use fertilizers. However, subsistence crop producers stop to use fertilizers which indirectly affects their water security when the priority is given to the fertilizer users. In general, the large plot holders and the banana growers who are influential and those who abstracts water illegally are concentrated at the head-end and middle of the scheme while the less influential farmers with limited access of the water are located at the middle and tail- end of the scheme. This shows that the location over the scheme primarily affects the water distribution.

\section{Statement on Conflicts of Interest}

All the authors do not have any possible conflicts of interest.

\section{References}

[1] Ambaye,. (2012). Land rights in Ethiopia: Ownership, equity, and liberty in land Use rights. In FIG Working Week (p. 27).

[2] Amede, T. (2014). Technical and institutional attributes constraining the performance of Small-scale irrigation in Ethiopia. Water Resources and Rural Development.

[3] Awulachew, S. B.; Merrey, D. J.; Kamara, A. B.; Van Koopen, B.;(2005) De Vries, F. Penning; and Experiences and Opportunities for Promoting Small-Scale/Micro Irrigation and Rainwater Harvesting for Food Security in Ethiopia. IWMI Working Paper 98.

[4] Bantero, B., Ayana, M., \& Awlachew, S. B. (2008). Across system comparative assessment Of irrigation performance of community managed scheme in Southern Ethiopia.

[5] Barrientos, L. E. M. (2010). Devolving resources and power in a context of land and water reform. Organising practices, resource transfers and the establishment of a WUA in the Little Thukela catchment, South Africa.

[6] Cherre, S. (2006). Irrigation policies, strategies and institutional support conditions in Ethiopia. In Best practices and technologies for small scale agricultural water management in Ethiopia. Proceedings of a
MoARD/MoWR/USAID/IWMI Symposium and Exhibition held at Ghion Hotel, Addis Ababa, Ethiopia, and 7-9 March, 2006. (p. 113). IWMI.

[7] Gebre-Selassie \& Bekele (2008) Review of Ethiopian Agriculture: Roles, Policy and Small- scale Farming Systems. Global-growing. org.

[8] Girma, M. M. A., \& Seleshi, B. (2007). Irrigation practices in Ethiopia: Characteristics of Selected irrigation schemes (Vol. 124). IWMI.

[9] Hanjra, M. A., Ferede, T., \& Gutta, D. G. (2009). Reducing poverty in sub-Saharan Africa Through investments in water and other priorities. Agricultural Water Management, 96 (7), 1062-1070.

[10] Lefort, R. (2012). Free market economy, 'developmental state 'and party-state hegemony in Ethiopia: the case of the 'model farmers'. The Journal of Modern African Studies, 50 (04), 681-706.

[11] Meinzen-Dick, R. (2014). Property rights and sustainable irrigation: A developing country Perspective. Agricultural Water Management, 145, 23-31.

[12] MoARD, (2010) Federal Democratic Republic of Ethiopia Ministry of Agriculture and Rural Development; Ethiopia's Agricultural Sector Policy and Investment Framework (Pif) 2010- 2020: Draft Final Report 15 September.

[13] MoFED, (2010); the Federal Democratic Republic of Ethiopia; Growth and Transformation Plan (GTP) 2010/112014/15; Draft Ministry of Finance and Economic Development; September 2010 Addis Ababa Retrieved from; http://www.ethiopians.com/Ethiopia_GTP 2015.pdf

[14] Mhembwe, S., Chiunya, N. \& Dube, E., (2019). The contribution of small-scale rural irrigation schemes towards food security of smallholder farmers in Zimbabwe', Jàmbá: Journal of Disaster Risk Studies 11 (1), a674. https://doi.org/10.4102/jamba.v11i1.674

[15] Tesfaye, A.; Bogale, A.; Namara, R. E.; Bacha, D. (2008). The impact of small-scale irrigation on household food security: The case of Filtino and Godino irrigation schemes in Ethiopia. Irrig. Drain. Syst, 22, 145-158.

[16] Bacha, D.; Namara, R.; Bogale, A.; Tesfaye, A. (2011). Impact of small-scale irrigation on household poverty: Empirical evidence from the Ambo district in Ethiopia. Irrig. Drain, 60, $1-10$.

[17] Bekele, W.; Drake, L. (2003). Soil and water conservation decision behaviour of subsistence farmers in the Eastern Highlands of Ethiopia: A case study of the Hunde-Lafto area. Ecol. Econ, 46, 437-451.

[18] Burney, J. A.; Naylor, R. L. (2012). Smallholder Irrigation as a Poverty Alleviation Tool in Sub-Saharan Africa. World Dev, 40, 110-123.

[19] Gebrehaweria, G.; Regassa, E. N.; Stein, H. (2009). Poverty reduction with irrigation investment: An empirical case study from Tigray, Ethiopia. Agric. Water Manag. 96, 1837-1843.

[20] Delgado, C. L. (2009). Sources of growth in smallholder agriculture integration of smallholders with processors in SubSaharan Africa: The role of vertical and marketers of high value-added items. Agrekon, 38, 165-189. 